\title{
Rival Versions of Objective Spirit
}

\author{
Mark Alznauer
}

\begin{abstract}
To assert the primacy of objective spirit is to claim that certain distinctively human capacities, such as thinking and acting, are not capacities we have as individuals considered singly but are in some way dependent on shared public norms or social institutions. In this essay, I provide a brief history of arguments for the primacy of objective spirit from Hegel to the present, identifying three distinct strategies for defending this thesis: the teleological argument, the sociological argument and the quasi-transcendental argument. Although it has now become quite common to read Hegel as advancing a quasi-transcendental argument, one similar to the argument found in Wittgenstein's famous remarks about 'rule-following', I show that Hegel's most interesting claims about the social dimensions of human mindedness are incompatible with this strategy and can only be vindicated if he is read as offering a teleological argument.
\end{abstract}

Even those who find little else of value in Hegel's philosophy have often found his notion of objective spirit to be worthy of attention, for with that term Hegel offers us a way to capture the irreducibly inter-subjective dimensions of human life. By emphasizing the primacy of objective spirit, Hegel opened debate on what remains a very interesting, if controversial thesis: the idea that some distinctively human capacities, such as thinking or acting, are not capacities we have as single individuals but depend in some way on social norms or institutions. Although Hegel's basic thesis about objective spirit has been very influential, it was long believed that the only way to make the concept of objective spirit compatible with a genuinely scientific approach to history and society was by divorcing it from its context in Hegel's philosophic system, which was seen as thoroughly tainted by an implausible Geist-metaphysics, and employing it in new ways. Over the last few decades, however, attempts have been made to show that Hegel's own argument for the primacy of objective spirit does not rely on any antiquated metaphysical commitments, but is similar to, or even identical with, the kind of argument found in Wittgenstein's famous remarks about rule-following. In the following, I hope to show that this revisionist interpretation of Hegel's theory of objective spirit is deeply flawed; Hegel's most interesting claims about the social 


\section{Objective Spirit}

dimensions of human mindedness are incompatible with the seemingly similar claims we find in Wittgenstein (and elsewhere), and so must be defended with a different kind of argument.

To see how we have gotten to where we are, it is helpful to get some historical perspective on the kinds of arguments that have been made for the importance of objective spirit since Hegel wrote. So in the first part of my essay, I provide a short history of the concept from Hegel to the present, identifying three distinct strategies that have been used to defend the idea that human activity depends on objective spirit (however that is understood). The first, the teleological argument, is the one that is traditionally ascribed to Hegel himself. According to this argument, humans are essentially social because they have a telos that can only be fully realized in a particular political condition. The second strategy, the sociological argument, is given its most influential formulation by Wilhelm Dilthey and is consciously predicated on a rejection of Hegel's own approach to defending the concept. This argument is much more modest than Hegel's; it only attempts to establish the empirically verifiable thesis that cultural patterns, norms, and institutions play a crucial role in structuring human life. The third strategy, the quasi-transcendental argument, can be found in the writings of Heidegger and Wittgenstein. According to this argument, all distinctively human thought and action conceptually presuppose a setting in a linguistic community. The promise of this third strategy is that it offers more than empirical generalizations about the importance of social phenomena while avoiding any potentially dubious teleological arguments.

In the second part of my essay, I show that it has become quite common in our own time, especially among readers influenced by Wittgenstein, to reject the traditional interpretation of Hegel, which reads him as advancing a teleological argument, in favour of an interpretation that draws him much closer to the third of these strategies: the quasi-transcendental argument. According to these commentators, Hegel's argument for the primacy of objective spirit is not that humans must enter into a certain political condition in order to realize their telos or essence, but rather that human thought and activity necessarily presuppose some social context and are inconceivable without it.

In the third part of my essay, I argue that the Wittgensteinian interpretation of Hegel is both textually indefensible and incompatible with some of Hegel's most interesting claims about objective spirit. It is textually indefensible because it is conflicts with Hegel's teaching about slavery which he understands as a form of human mindedness that exists outside of objective spirit (something that should be impossible according to the quasi-transcendental argument). It is incompatible with Hegel's own views because it implies that the conditions for moral autonomy are present in any human society and thus do not require the establishment of rational political institutions. Since what we need to vindicate 


\section{Mark Alznauer}

Hegel's thesis is an argument as to why rational beings must achieve moral autonomy, not an argument as to why they must always already have it, I conclude that only the teleological argument offers the right kind of support for Hegel's theory of objective spirit.

\section{A brief history of objective spirit}

Although there are certainly historical antecedents for the notion of objective spirit-most notably, perhaps, Montesquieu's concept of esprit in On the Spirit of the Laws-it has its locus classicus in Hegel's mature Encyclopaedia system. ${ }^{1}$ In the third and final part of the Encyclopaedia, the Philosophy of Spirit, Hegel divides spirit (or mind) into three categories: subjective spirit, objective spirit and absolute spirit. He characterizes these three categories of spirit as stages (Stufen) that spirit traverses along the path to full self-knowledge of its concept (Begriff) or essence (Wesen) (PM: \$385). ${ }^{2}$ Hegel's way of talking about the development of spirit as if it were a kind of Bildungsroman is obviously metaphorical, but according to almost all interpretations of Hegel prior to the end of the twentieth century, the notion of development itself needs to be taken quite literally. Hegel's claim is not that spirit always manifests these three aspects, but that it necessarily develops through three stages. In making the transition from one of these stages to another, spirit is said to achieve a deeper or more adequate knowledge of what it is to be spirit at all, of what it is to be free or self-determining.

There are two things worth emphasizing about the kind of argument for objective spirit which is implied by this traditional way of reading Hegel. First, on this reading subjective spirit depends on objective spirit not in order to exist but only in order to actualize itself: that is, to achieve a higher, more adequate level of self-knowledge. If Hegel's developmental language should be taken literally, it would seem that he cannot be claiming that objective spirit is a condition for the existence of the kinds of mental activities described in subjective spirit-that would be like claiming that being an adult is a necessary condition for being a child. He is saying, rather, that subjective spirit must become or transform itself into objective spirit.

The second thing to note is that, on these readings, Hegel's notion of objective spirit is not employed to cover all inter-subjective phenomena, such as language or social interaction as such, but has a very specific content: the laws and customs of the state. This is certainly the most natural reading of Hegel, since he is quite explicit that the inter-subjective relations between individuals only take on objectivity in the relevant sense when they come to reflect the requirements of the concept of right (PM: $\$ 486)$. According to this reading, then, inter-subjective norms and institutions count as objective spirit in the 


\section{Objective Spirit}

proper sense only to the degree that they embody the conditions of human freedom. This is why Hegel treats the laws and customs of objective spirit as intrinsically normative or authoritative. ${ }^{3}$

In thinking about what it means to make an argument with these two features, it is helpful to note the similarity between Hegel's argument for the primacy of objective spirit and Aristotle's argument that man is a political animal. ${ }^{4}$ Both involve the claim that humans have an end (a telos or Begriff) that can only be fully realized or achieved in a particular political condition (the polis or the Rechtsstaat). Just so we have a handle on this as a specific type of defence of objective spirit, I will be referring to it as the teleological argument. As is reasonably well known, Hegel's crucial twist on this otherwise Aristotelian argument was to historicize it. He argued that the political institutions required for the actualization of human freedom were not fully present in the Greek polis; they developed gradually over time and only fully emerged in the modern European state.

Whether accurate or not, this was certainly the picture of Hegel that subsequent philosophers and theorists would target. Indeed, it did not take long before Hegel's account of the modern European state as embodying the rational requirements of freedom came under attack. During the period immediately after his death, discussions of objective spirit largely disappeared in favour of supposedly more scientific treatments of human society such as that championed by Leopold von Ranke. For Ranke, whose criticisms of Hegel would be repeated many times over the next century, any truly scientific approach to history had to be inductive and empirical, whereas Hegel's approach was hopelessly deductive and a prioristic. ${ }^{5}$

The notion of objective spirit first re-emerged in the Völkerpsychologie of Moritz Lazarus and Hajim Steinthal where it was scrubbed clean of its metaphysical and teleological presuppositions and redeployed in order to investigate the psychological aspects of human culture. And then in the early twentieth century, it was taken up by two of Lazarus's former students, Wilhelm Dilthey and Georg Simmel, who found it a useful way of characterizing the proper object of the human sciences. Through the work of Dilthey and Simmel, the notion of objective spirit became a subject of intense reflection again. In this new climate, there was no interest in defending the specific function that the notion of objective spirit played in Hegel's system; it was simply taken for granted that Hegel's a prioristic approach to human reality had been completely superseded by the rise of the empirical social sciences. The hope was that the concept could be redeployed in order to identify the specific realm of phenomena that the social and historical sciences treat, demonstrating the importance or irreducibility of those sciences.

Dilthey's account of objective spirit in Der Aufbau der geschichtlichen Welt in den Geisteswissenschaften (1910) is particularly explicit about what is involved in this new 


\section{Mark Alznauer}

application of the concept. The first difference that Dilthey points to between his notion and Hegel's is that whereas 'Hegel constructed metaphysically; we analyze the given' (Dilthey 1976: 194). Dilthey finds that Hegel's analysis of objective spirit is guided by an antecedently established conception of the rational or free will: it is primarily concerned with showing which particular aspects of social and historical reality are required for the actualization of freedom. Dilthey, however, is interested in making room for an analysis of historical and social reality that is unconstrained by any a priori philosophical commitments as to the necessary conditions for the actualization of human freedom. The approach he prefers is intended to be purely empirical, to describe things exactly as they happen to be, not as they should be or must be.

This methodological difference leads directly to the second difference between Dilthey's use of objective spirit and Hegel's: a dramatic widening in the content of the concept. Dilthey argues that once we divorce the concept of objective spirit from its function in Hegel's thought, a new conception of it becomes possible, one that embraces not only family, society, the state and the law but also every other form in which human spirit expresses itself publicly. This explicitly includes 'language, custom, and every form and style of life' as well as all of those phenomena that Hegel included under the higher category of absolute spirit: art, religion, and philosophy (Dilthey 1976: 194). In Dilthey's hands, then, objective spirit is transformed from a term that picks out just those laws and customs necessary for the realization of human freedom to a term that covers all of human culture: not just shared norms of every sort but even cultural artefacts, texts, and so forth.

These two features characterize a second, distinct kind of argument for the importance of objective spirit. Because of its reception history, I want to call this the sociological argument for the dependence of subjective spirit on objective spirit. According to the sociological argument, subjective spirit depends on objective spirit because the cultural patterns, structures and institutions that make up objective spirit play an overwhelmingly important role in influencing human thought and action. Insofar as these cultural patterns and so forth are internalized in our upbringing, they play a genetic role in making us who we are. And insofar as they determine the courses of action that are available to us, they serve as the context in which any individual action takes place, a context that both constrains and enables human action. The sociological argument contends that human activity is decisively or strongly influenced by a broad array of social and cultural factors, and reserves the job of determining the actual forms and extent of this influence for the empirical social and historical sciences.

What eventually gives rise to a third defence of objective spirit is not a worry that the sociological approach is wrong about the importance of social and cultural factors, but rather that it does not go far enough, that it underestimates 


\section{Objective Spirit}

how deeply social human thought and action actually is. Interestingly enough, this third kind of defence of objective spirit has also been traced back to Dilthey. In his early Kassel lectures, Heidegger claims to find a much stronger defence of the priority of the social in Dilthey: the claim that human life does not just happen to be embedded in society and history, but is ontologically social and historical. ${ }^{6}$ The reason this second insight never fully emerges in Dilthey's writings, Heidegger says, is because he lacked the philosophical means to justify it. These means were only provided by Husserl's development of the phenomenological method, which reveals that all human existence is shot through with intentionality. It is only from this phenomenological basis that it can be shown, as Heidegger himself would attempt to do in Being and Time (although with a radically revised conception of intentionality), that sociality and historicity are not just contingent features of human life, however important, but among the constitutive conditions for any meaningful relation to the world at all. ${ }^{7}$ If sociality is a constitutive feature of all intentionality, then it really makes no sense to say that human activity is strongly influenced by our social context and historical inheritance; for that way of talking presupposes that we can separate out the social and historical factors from individual ones.

A similar set of considerations can be found in the later works of Ludwig Wittgenstein and play a prominent role in Peter Winch's well-known attempt to provide a philosophical foundation for the social sciences (Wittgenstein 1953; Winch 1958). Winch thought the sociological approach to human social life was built on a fundamental mistake concerning the nature of its own foundations. Although sociologists often recognize the way that particular concepts depend on the life of the society in which they circulate, they fail to see that this dependence on a social setting was no empirical truth about certain concepts, but reflects an $a$ priori logical truth about the conditions under which the use of any concepts is possible at all. This specifically conceptual truth, Winch argues, is demonstrated by Wittgenstein's remarks on following a rule in the Philosophical Investigations, which showed that all rule-following presupposes a linguistic community. Once that argument is seen in its proper scope, as applying to all thought and action, the conclusion can be drawn that it is strictly incoherent to think of human cognition apart from its social context.

Two things are worth underlining about the basic approach to the social aspects of human life which is shared by Heidegger and Wittgenstein (at least as Winch interprets the latter). The first is that the importance of sociality in human activity is no longer taken as an empirical claim, but as a conceptual or philosophical truth about the nature of human existence as such. ${ }^{8}$ This revival of interest in a philosophical, even a priori approach to sociality does not signify a reversion to the teleological argument, however. The claim is not that that humans must enter into certain specific social relations in order to more fully 
realize their essence or concept, but that thought and intentional action are literally inconceivable or impossible apart from a social setting. The second thing worth mentioning is that the chief illustration of the importance of sociality for both Heidegger and Wittgenstein is no longer laws or even culture but language-language not as a tool by which we think about the world but as something by which the world is disclosed to us in the first place.

To be sure, neither Heidegger nor Wittgenstein had any interest in recasting their insights about human sociality into Hegelian vocabulary, however attenuated. Most contemporary defences of the concept of objective spirit, however, clearly stand downstream from these two thinkers, borrowing their ways of thinking. Notable versions of this third way of conceptualizing objective spirit have been provided by Charles Taylor and, more recently, Vincent Descombes. Taylor and Descombes attempt to vindicate the concept in a way that retains the two features that I have just identified as characteristic of the Heideggerian or Wittgensteinian approach to sociality: the reliance on claims about conceptual necessity, and the focus on language. ${ }^{9}$ The appeal of this strategy is that it offers us a way of capturing Hegel's basic insight into the sociality of human thought and action without taking any of his ambitious metaphysical and teleological commitments on board. Following Gillian Rose, I will call arguments for objective spirit that take this form quasi-transcendental arguments (Rose 2009: 15). ${ }^{10}$ According to the quasi-transcendental argument, the importance or primacy of objective spirit is due to the fact that all distinctively human thought and action would be inconceivable without language, and language presupposes a setting in a linguistic community. On this third view of objective spirit, the human mind is not just strongly influenced by social factors; it is intrinsically or necessarily social, social according to its very concept.

\section{The Wittgensteinian interpretation of Hegel}

Although figures such as Dilthey, Simmel, Taylor and Descombes all found new ways to defend the concept of objective spirit, they did so quite conscious of the fact that they were redefining the notion as well-replacing Hegel's notion of objective spirit with something else, something that picks out a different, wider range of social phenomena (Descombes 2014: 291). But over the last two decades, it has become increasingly common for interpreters, especially in the Anglophone world, to offer revisionist interpretations of Hegel that assimilate his approach to sociality to the kind of quasi-transcendental approach that Winch found in Wittgenstein. ${ }^{11}$ Michael Forster's book, Hegel's Idea of a Phenomenology of Spirit, perhaps offers the most fully fleshed-out example of this way of reading Hegel. Forster claims not only that Hegel put forth an argument that is 'virtually identical' 


\section{Objective Spirit}

to Wittgenstein's remarks on rule-following in the Pbilosophical Investigations, but also that Hegel's argument is better since it exhausts the counter-possibilities more systematically (Forster 1998: 207). On Forster's reading, the first half of the Phenomenology of Spirit is intended to show us that every form of consciousness that resists the idea that concept mastery is something other than shared linguistic behavior necessarily fails. The upshot of this failure is a proof of the thesis that concept use is intrinsically linguistic and social. ${ }^{12}$ Similar accounts of the Phenomenology have since been offered by several others. ${ }^{13}$

The Wittgensteinian interpretation of Hegel has been so successful that it is now quite common to simply identify objective spirit with the realm of rulefollowing as such. Paul Redding offers us a particularly clear and succinct statement of what it looks like to interpret Hegel's dependency thesis in this manner:

In something like the picture found in the thought of the later Wittgenstein, Hegel makes it a condition of mindedness that an individual belongs to a social realm of rule-governed interactions: it is this realm that is where that individual can find the recognition that is a condition of their being a selfconscious individual. Thus the study of the conditions of subjective spirit takes us to the realm of objective spirit-spirit as it is 'objectified' in those forms of finite, culturally encoded normative (or rule-following) practices and institutions in which an individual 'subjective spirit' engages with others. (Redding 2008: 145)

Note that the claim Redding is attributing to Hegel in this passage is that objective spirit is a condition for the very possibility of mindedness. Redding also claims that language is the most important of objective spirit's 'mind-bearing cultural scaffolds' (Redding 1999: 128). These two commitments clearly mark his reading of Hegel as quasi-transcendental in the sense I identified above.

Given the traditional, teleological reading of Hegel's argument that I sketched above, it might look as if there are two obvious reasons why a Wittgensteinian reading of Hegel is unlikely to get off the ground. First, if Hegel's argument is rightly characterized as having a developmental structure, then a quasi-transcendental defence of objective spirit would appear to offer it the wrong kind of support. The problem is that you cannot justify a claim that subjective spirit must develop into objective spirit by denying that subjective spirit is even conceivable apart from objective spirit. In fact, if the quasi-transcendental argument is correct, and sociality is a condition of mindedness, then the selfactualization argument is unintelligible, for it posits a transition from an impossible condition to a necessary one. 


\section{Mark Alznauer}

The second reason why the quasi-transcendental approach might seem poorly suited to vindicate Hegel's notion of objective spirit is because it appears to equivocate on the notion to be vindicated, de-politicizing it. On the traditional reading, Hegel's defence of objective spirit concerns the relationship between individuals and the rational laws and customs of their state, not between individuals and linguistic norms or shared social practices more generally. Indeed, since Hegel treats language in Subjective Spirit, it would appear that even a successful demonstration that mindedness presupposes a setting in a linguistic community would leave us well short of showing the necessity of objective spirit as Hegel himself understands the notion. ${ }^{14}$

To some extent, both of these considerations can be allayed by turning to the account of sociality provided in the Phenomenology of Spirit which has served as the central text for the Wittgensteinian reading. The Phenomenology passes through the same basic stages as we see in the later Philosophy of Spirit, moving from the 'shapes of consciousness' treated in the first five chapters (subjective spirit before the letter) to the 'shapes of a world' treated in the Spirit chapter (the precursor of objective spirit). Although this progression through stages is what you would expect from the self-actualization argument, in the Phenomenology Hegel argues that spirit is not just the destination at which we are aiming, but also the presupposition of the former stages. He says:

All previous shapes of consciousness are abstract forms of [Spirit]. They result from Spirit analyzing itself, distinguishing its moments, and dwelling for a while with each. The isolating of those moments presupposes Spirit itself and subsists therein; in other words, the isolation exists only in Spirit which is a concrete existence. (PhS: $\mid 440 / P h G: 239)$

This passage suggests that there is no incompatibility between the developmental and the quasi-transcendental strategy, for the development we see depicted in the Phenomenology is only the process of coming to understand that some kind of social setting was a necessary condition for existence of mindedness all along. Indeed, it is just this basic strategy that most Wittgensteinian interpreters have attributed to Hegel in the Phenomenology. As John McDowell puts it, the sections leading up to Spirit are intended to put 'consciousness on the path to learning ... that agenthood, like citizenship in Rousseau, is not intelligible except in the context of the idea of communal life' and this is because the very 'idea of conceptual capacities makes sense only in the context of shared practice' (178). The idea here is that the development we see in the Phenomenology is no transformation in consciousness, but only consciousness coming to understand what it necessarily was all along.

The second issue, the concern with the de-politicization of objective spirit, also appears more manageable when it is approached via the Phenomenology. 


\section{Objective Spirit}

For although the Spirit chapter does focus on broadly political phenomena, such as the conflict between the divine law and the human law in Ancient Greece, Hegel's particular historical examples in the Phenomenology can easily be read as extended metaphors for linguistic or discursive phenomena more generally. Indeed, Hegel himself seems to licence such a reading by characterizing language as the very Dasein of Geist, which certainly suggests a much broader conception of objective spirit than one restricted to laws and customs of rational states (PhS: 9652).

Of those who take this approach, Robert Brandom is perhaps the most explicit about treating the apparently political aspects of the Phenomenology as allegorical. For Brandom, the Spirit chapter is not the genealogy of law in Western history that it appears to be, it is actually an account of the concept-use in general which uses law as a convenient way to make the problem of the authority of concepts salient to the reader. But McDowell makes essentially the same claim, contending that the 'content' discussed in the Spirit chapter - that is, the particular political conceptions of what it is to have a reason which had their home in the Greek polis, Roman empire, etc.-is incidental to Hegel's true philosophical aim, which is just to equip us with the right understanding of what it is to be an autonomous member of the space of reasons at all (McDowell 2009: 181-82). For both Brandom and McDowell, what appears to be a discussion of a succession of a specific form of normative authority - that involved in the relation between the citizen and the state-is actually a metaphorical treatment of the social dimensions of all concept-use or responsiveness to reasons.

\section{Against the Wittgensteinian interpretation of Hegel}

There are, of course, deep and interesting disagreements amongst Wittgensteinian interpreters of Hegel concerning the philosophical function of the appeal to sociality. But all of these disagreements concern different ways of executing the same project, which is to read Hegel as advancing a quasi-transcendental argument for the primacy of objective spirit, one that advances the claim that human mindedness is intrinsically social because it presupposes a setting in a linguistic or discursive community. It is this basic argumentative strategy that I mean to challenge, first on textual groundson the grounds that it fails to capture what is most distinctive about Hegel's viewand then on substantive grounds, as both incompatible with what Hegel has to say, and significantly less interesting.

To make the textual case, we can start by looking at the way the Encyclopaedia characterizes the transition from subjective spirit to objective spirit:

Whereas subjective spirit, owing to its relationship to its other, is still unfree, or what it is the same thing, is free only in itself, in 


\section{Mark Alznauer}

objective spirit freedom, mind's knowledge of itself comes into existence [Dasein]. Objective spirit is a person, and as such has the reality [Realität] of its freedom in property; for in property the thing is posited as what it is, namely, as lacking independence and as something that essentially only has the meaning of being the reality of the free will of a person and, for that reason, of being for any other person something inviolable. Here we see a subjective entity [ein Subjectives] aware of itself as free, and, at the same time, an external reality of this freedom; here, therefore, spirit attains to being-for-itself [Fürsichsein], the objectivity of spirit receives its rights. (PM: \$385Z, translation modified)

There is a lot of Hegelian terminology in this passage that could use disambiguation but Hegel makes one thing perfectly clear, which is that objective spirit has no reality [Realität] apart from rights-bearing persons and property. Objective spirit is ontologically dependent on there being individuals who have property rights; it only exists insofar as there are such individuals. This rules out any interpretation of objective spirit as some transcendent entity intervening in human affairs from the heavens. But it does not yet help us to adjudicate between the two interpretations of Hegel we are examining, for the self-actualization argument and the quasi-transcendental argument offer us two quite different ways of understanding what it means to attain the 'being-for-itself' which is definitive of objective spirit.

According to the self-actualization argument, the transition spoken of here involves a real transformation in human existence, one that takes individuals from an identifiably human condition in which they are only potentially persons with property rights to a new condition in which they have finally attained this status, actualizing that potential. We have already seen, though, that quasi-transcendental readers have a way of recasting what appear to be transformations from one ontological condition to another as involving only the process by which we come to understand something that was actually true all along. In this case, that would mean reading the move from subjective and objective spirit as marking only the transition from not knowing that we are rights-bearing persons to knowing it.

The decisive difference between these two interpretations, then, concerns their respective characterizations of the status of those human beings who are not aware of their freedom, who do not take themselves to be persons with property rights. That is to say, they differ on the how they regard the slave, for Hegel defines slavery as precisely that condition in which humans are only free implicitly, not yet explicitly or consciously (see, e.g., PR: \$21A, \$26 and R). According to the self-actualization argument, the slave's failure to take himself to 


\section{Objective Spirit}

be a person entails a failure to be a person. It is only by both becoming conscious of their freedom and achieving external recognition by the state that slaves can achieve this status. It follows from this that during any historical period that lacks general consciousness of freedom, it cannot be said that anyone's rights are being wronged by slavery. According to the quasi-transcendental interpretation, on the other hand, if someone fails to take herself as a person, she is simply making a mistake. Slaves are already rights-bearing persons, they just don't know it yet. This entails that whenever and wherever people are treated as slaves, their rights are being violated.

The question we have then is this: when a slave becomes conscious of his freedom, does Hegel think that he becomes a rights-bearing person, or only that he comes to realize that he is and always has been such a person? Once the question is posed this way, it is not hard to determine Hegel's answer. Hegel is insistent that slaves as such have neither rights nor duties (PR: $\$ 261)$, that when slavery occurred it involved no injustice to the slaves (PM: \$435Z), and that the slave only attains the capacity to hold rights by taking possession of his personality (PR: $₫ 66 \mathrm{R})$. Unlike Kant, Hegel clearly denies that we have natural rights to anything, even our bodies; for him, all rights need to be consciously acquired (PR: \57). Insofar as the slave has not consciously asserted any right to his body, nor been recognized as having such a right, he is not yet a person in Hegel's sense- that is, he is not a bearer of rights claims. ${ }^{15}$ In this, the slave is in fact not alone; for Hegel thinks that there are entire peoples 'that do not have personality' (PR: $₫ 35) .{ }^{16}$

What all of these passages indicate is that, on Hegel's understanding, slaves, at least in the pre-Christian world, were not rights-bearing persons who did not know that they had rights. They were potentially free persons who had yet to achieve or realize the status of personhood. The logic of the transition from subjective spirit to objective spirit is not Wittgensteinian but Aristotelian: for when an individual goes from being free 'in itself' to being free 'for itself' she is not making explicit something that was already implicitly true, she is actualizing something that, up to that point, existed only as a potentiality. ${ }^{17}$

My argument, thus far, has been limited to showing that Hegel's own defence of objective spirit in the Philosophy of Spirit cannot be understood as a quasi-transcendental argument. ${ }^{18}$ The problem is that any transcendental or quasi-transcendental argument is characterized by a claim that some x would be impossible if not for some $\mathrm{y}$, but if we read subjective spirit as $\mathrm{x}$ and objective spirit as $y$, then we are forced to attribute the claim to Hegel that all human thought and action would be impossible if not for recognized persons and propertyrelations. But Hegel denies this - and nowhere more clearly than in his treatment of slavery, which is a treatment of human beings who think and act, sing and worship, and yet who lack the status of personhood. Since slavery is certainly possible, and represents a form of mindedness that falls short of objective spirit, 


\section{Mark Alznauer}

Hegel cannot have intended the transition to objective spirit to be understood as a quasi-transcendental argument.

But even if the quasi-transcendental interpretation of this particular transition fails, we have not yet shown that the substantive claim in which the Wittgensteinian interpreters are invested is incompatible with the substantive claim that I've just attributed to Hegel. The difference between these, you will recall, concerns not only the form of the argument, but also different conceptions of objective spirit itself: whether it refers to all discursive or linguistic practices (as the Wittgensteinians contend) or only to the laws and norms of the Rechtsstaat (as Hegel apparently thinks). But regardless of what Hegel himself actually meant by the term, we have not yet seen any reason to think that someone could not assert both that mindedness in general is impossible apart from the existence of a linguistic community and that human spirit is only fully actualized in a particular community represented by the Rechtsstaat.

Certainly these two claims could be formulated in a manner that renders them compatible. To do so, all we would need to do is to distinguish those mental or spiritual capacities that we acquire when we become language users from those capacities that we acquire when we become recognized as citizens. But that there is deep philosophical dispute between the Wittgensteinian and Hegelian approaches becomes clear once one asks whether moral autonomy is the sort of capacity that only comes with belonging to a language community or whether it is the sort that only comes with citizenship. By moral autonomy, I mean something that is potentially distinguishable from rational autonomy. If rational autonomy is the capacity to act on reasons that one recognizes as one's own, then moral autonomy is the capacity to act on reasons that one not only recognizes as one's own, but which one also accepts as obligatory or binding in a moral or ethical sense. ${ }^{19}$ At this point, I mean to leave open the question of whether the former sort of autonomy is actually distinct from the latter-as we will shortly see, that is exactly what is at issue between these two rival approaches to objective spirit.

The general thesis that moral autonomy has social preconditions is, of course, shared by both approaches. This thesis has its modern origins in Rousseau's On the Social Contract. In that work, Rousseau argues that it is only if individuals found themselves in the specific, and unfortunately highly unlikely, circumstances of an ideal commonwealth that we could say that they were obeying laws that they had given themselves rather than laws that represent an alien authority. In the absence of these conditions, such individuals would not only lack freedom in the civic sense, but they would also lack moral autonomy. As Frederick Neuhouser explains, 'in the absence of those features that make a community and its interpretations of the general will worthy of its citizens' trust, the conditions that make rational obligation possible do not obtain' (Neuhouser 2008: 215). ${ }^{20}$ This suggests that, for Rousseau, moral autonomy in the sense that we have defined it is impossible 


\section{Objective Spirit}

outside the ideal commonwealth, because it is only in the ideal commonwealth that the laws that we are under can be said to be obligatory or rationally binding.

Although both the Wittgensteinian and Hegelian approaches to objective spirit agree with Rousseau that moral autonomy depends on some social context, neither can adopt Rousseau's particular account of how this works. By looking at the modifications that they think need to made in Rousseau's account in order to remedy its deficiencies, we can see exactly where these two accounts diverge. Recently, both Robert Brandom and John McDowell have provided alternative sketches of how their own conceptions of autonomy are related to Rousseau's. These will serve as my examples of the broadly Wittgensteinian approach.

For Brandom, social contract theories such as Rousseau's rightly recognize that all political obligation rests on the attitudes of the governed, in particular, on their consent to or acknowledgement of these obligations. But Brandom thinks that the focus on the problem of justified political authority that is characteristic of these theories gives rise to two related limitations (Brandom 1998: 51; see also Brandom 2009). The first is that these theories under-generalize their chief insight: it is not only political obligations that are attitude dependent, Brandom thinks, but all normative statuses. According to Brandom, it was Kant's great achievement to recognize that Rousseau's model of autonomy could be generalized to explain how we become subject to the authority of any concept or norm, not only the norms we see in the political sphere. To accomplish this transposition successfully, though, a second problem in social contract theories needs to be addressed, which is that these accounts model normative relations on the hierarchical relation between an inferior (a citizen) and a superior (the state). It was Hegel who was able to take this second step beyond the social contract theories. He did this by showing that determinate normative statuses such as obligation are actually only possible by means of fully symmetrical relations between individuals, relations of mutual recognition. According to the resulting picture, there is nothing special about moral autonomy - our capacity to bind ourselves to moral obligations is just a particular form of our capacity to bind to ourselves to any concept, a form distinguished only by its particular content. In both cases, the recognitive attitudes of two individuals are jointly sufficient for the institution of a binding norm; it makes no difference whether we are talking about a norm concerning the right way to use a concept or one concerning the right way to act.

McDowell's version of the story is certainly different from this. For him, Rousseau's account of freedom is not important because it traces the authority of obligations to our attitudes, as Brandom asserts, but rather because it points us to a model of autonomy as responsiveness to reasons as such (see McDowell 2010). But McDowell fully agrees with Brandom that Rousseau's account was unduly constrained by political considerations. Kant's achievement, he says, was to recast Rousseau's ideal commonwealth as a metaphor for the kingdom of ends, thus 


\section{Mark Alznauer}

'freeing Rousseau's conception from its specifically political setting' (McDowell 2014: 15). By doing so, McDowell thinks, Kant retained Rousseau's idea that we are only free if we are subject to laws of which we could be considered the author, but Kant showed that this is obtained in the moral sphere regardless of the political circumstances. What the Hegelian emphasis on sociality adds to this is not a denial of the Kantian idea that autonomy is a capacity that individuals have as individuals, but just a recognition that our capacity for moral autonomy could only come into existence in the actual social context of some linguistic community. Here sociality plays a crucial role in the genesis of moral autonomy but is not constitutive of it; once we have acquired this capacity we do not need any particular social context in order to exercise it. According to this view, it is the very same transformation that makes us capable of acting at all that provides us with the capacity for moral autonomy (McDowell 1998: 189). For once we have the capacity to consider alternative courses of action, and thus to act on mere practical reasons, we must also have the capacity, and indeed the obligation, to examine critically whether a potential reason to act is in fact a good one.

So although these two Wittgensteinian accounts are quite different in some important respects, they share the belief that once the social conditions are in place for rational autonomy (that is, the capacity to act on reasons that one recognizes as one's own) then we have all we need for moral autonomy (the capacity to act on reasons considered as obligatory). Brandom and McDowell credit Rousseau for recognizing that moral autonomy has social preconditions, but they both re-interpret that claim in a way that completely abstracts away from Rousseau's theory of the state.

But if we turn to Hegel's own treatment of Rousseau, in his Lectures on the History of Philosophy, we get an entirely different view of what is worth retaining from Rousseau's teaching about autonomy. Hegel agrees with Brandom and McDowell that Rousseau's model of moral autonomy provides us with a model of norm-governed activity that is of use in other spheres, including the theoretical sphere into which Kant transposed it, but Hegel does not think this requires depoliticizing Rousseau's account of moral autonomy (LHP 3: 400-2/TWA 20: 306-8). ${ }^{21}$ In fact, Hegel commends Rousseau for recognizing that slavery is a condition in which humans live in contradiction with their essence as free, a condition in which they have 'no rights or duties'. Rousseau was also correct, according to Hegel's telling of the story, that this contradiction can only be overcome in a rational state, one that is organized in a way that 'each individual, while joining this association, obeys himself only'. So, whatever Hegel's disagreements with Rousseau, he fully concurs that genuine moral autonomy is impossible outside of the rational state.

Hegel's objections concern a certain ambiguity that attaches to Rousseau's own defence of that thesis. The first problem is that Rousseau wants to claim that 


\section{Objective Spirit}

in a rationally organized state, the individual 'remains as free as before', which suggests that there is a kind of freedom that pre-exists the state and which provides us with an independent normative standard by which we can judge the state. Against this, Hegel insists that the state is 'the first realization of freedom' (my italics); prior to the state, Hegel thinks, there was no freedom at all. The second, related problem is that Rousseau understands the rational state as an ideal that requires a rather unlikely convergence amongst the arbitrary wills of all of the citizen considered as individuals, rather than as a political organization that has a certain rational structure, one that can exist whether we are conscious of it or not. Because of this, Rousseau fails to understand that the conditions he is seeking do not await realization in some future utopia but are in fact already satisfied by existing states. ${ }^{22}$

Once one makes these modifications in Rousseau's account, one obtains the following picture. Humans outside the state, or in the state of nature, certainly have rational autonomy-they are capable of what Hegel calls mere volitionbut it is only when they enter into a civil condition that they become capable of moral autonomy, since it is only in such circumstances that they are subject to genuinely obligatory laws or norms. Like Rousseau, Hegel thinks that the conditions for moral autonomy are both distinct from, and harder to satisfy than, the conditions of rational autonomy. Somebody can have the capacity for rational autonomy, they can act on reasons, without yet having the capacity for moral autonomy, the ability to act on reasons that they see as necessarily binding or valid. For the latter, certain institutional requirements must be met. But unlike Rousseau, Hegel thinks that these conditions are fairly easy to satisfy-we do not need an ideal state, only one with a certain minimally rational structure.

If Hegel is right about all of this, it is not enough to explain how humans become capable of acting on reasons as such (in Hegel's system this is the transition from nature to spirit). We also need an account as to how we get from what one might call the space of reasons as such into the space of moral reasons. And this, we can now see, is exactly what Hegel's developmental account of the transition from subjective spirit to objective spirit is supposed to provide: it is supposed to explain the rational necessity involved in making the transition from mere rational autonomy to full-blown moral autonomy.

The substantive philosophical dispute between the Wittgensteinian and Hegelian defences of objective spirit is now fully in view. Although they both agree that rational autonomy has certain basic social preconditions, such as the existence of a language community, the Wittgensteinian approach insists that these basic conditions are also sufficient for the development of moral autonomy, whereas the Hegelian approach denies this. Genuine moral autonomy, on Hegel's view, is not coeval with the capacity to act on reasons, but requires a further step: it requires the establishment of rational political and social institutions. 


\section{Mark Alznauer}

\section{Conclusion}

My argument so far suggests that the core thought behind Hegel's philosophy of objective spirit is not that all human thought and action presuppose some social setting or other, but that all rights and duties have specific institutional prerequisites. ${ }^{23}$ This conclusion should not be entirely surprising; it has long been recognized that Hegel opposes the social contract tradition on just these grounds. According to the social contract tradition (Rousseau partly excepted), we enter into the state either to secure pre-existing rights or because we are under a moral obligation to exit the state of nature. It is common knowledge that Hegel objects to these accounts because they treat individuals and their interests as something that can exist independently of the state. But Hegel's objection is easy to misunderstand. Despite Hegel's protestations to the contrary, it is often thought that Hegel's primary issue with social contract theories is that they give us a misleading picture about how states actually arose, failing to recognize that the kinds of individuals which these accounts presuppose are obviously already the product of certain institutional arrangements. ${ }^{24}$ This objection has proved easy to brush off, for as many have noted, social contract theories are not intended as historical accounts, they are intended as hypothetical fictions. But Hegel's real problem with these theories is not that they are historically inaccurate but that they are conceptually incoherent, incoherent even when considered as mere thought experiments. These approaches attempt to justify the authority of the state in terms of rights or duties that we have independently of the state, but, if Hegel is right about the primacy of objective spirit, no one could possibly have any rights or duties apart from membership in a state. Even a simple contractual agreement between two individuals is only genuinely valid and binding, Hegel claims, if there is some authoritative institution in place to settle matters when there is a dispute, and that is precisely what is lacking in the state of nature.

From this point of view, Wittgensteinian accounts of objective spirit mark a clear regression to the normative standpoint of the social contract tradition. On such accounts, moral obligations are either fully present in the state of nature (as McDowell contends) or they can be viewed as rooted in acts that take place between individuals considered apart from any political institutions (as Brandom argues). But to concede either of these points requires reverting to exactly those Lockean or Hobbesian commitments that Hegel has taken such pains to overcome in the Philosophy of Right. Although the Wittgensteinian interpretation appears to radicalize Hegel's commitment to sociality by making it a transcendental condition of all thought and action, it has the actual effect of returning us to the pre-Hegelian idea that the normative standards by which the state is to be evaluated are already in place prior to the establishment of any political institutions. 


\section{Objective Spirit}

It should now be clear why the most distinctive and interesting aspect of Hegel's theory of objective spirit, his intrinsically institutional account of moral autonomy, must go missing in any attempt to revive that notion by recourse to Wittgensteinian or Heideggerian approaches to intersubjectivity. When we characterize human sociality in terms of the Wittgensteinian 'forms of life' or Heidegger's notion of Mitsein, we are treating it as a kind of hidden precondition of human thought, a precondition that we always risk overlooking, but that can be brought to light by the right kind of philosophical investigation. But when Hegel speaks of the primacy of objective spirit, he is saying not that it is the necessary condition for human mindedness but that it is a necessary stage in its development. He thinks that merely rational beings must enter into those relations constitutive of objective spirit in order to realize their essence or nature as free beings. To justify this claim, Hegel needs a sort of argument that has no obvious parallel in Wittgenstein or Heidegger: an argument capable of establishing not what must be but what must happen.

This takes us back to where we started, to the idea of a teleological argument. As we saw in section I, it is traditional to interpret Hegel's defence of objective spirit as claiming that spirit must achieve a certain level or stage of selfconsciousness in order to actualize its concept, or realize its telos. We can now see why this is the sort of argument that is needed in order to vindicate Hegel's most distinctive and interesting claims about human sociality. But to what extent can such a strategy be defended? Can a version of the teleological argument be articulated which is either free of the a priorism of Hegel's Geist-metaphysics or which offers us a defensible version of it? These are the deepest methodological questions facing any rehabilitation of Hegel's theory of objective spirit; they have only been obscured by the apparent similarity between Hegel's defence of objective spirit and contemporary versions of the same.

\section{Mark Alznauer \\ Department of Philosophy, Northwestern University, USA m-alznauer@northwestern.edu}

\section{Notes}

${ }^{1}$ For a survey of Hegel's uses of 'objektiver Geist', see Peperzak (2001: 116f. 8). According to Peperzak, Hegel started using the term in this sense in his 1817-18 Lectures on Natural Right and Political Science.

${ }^{2}$ Abbreviations: LHP $=$ Lectures on the History of Philosophy 1825-6: Volume 1: Introduction and Oriental Philosophy, trans. and ed. R. F. Brown (New York: Oxford University Press, 2009). 


\section{Mark Alznauer}

PhG = Phänomenologie des Geistes, ed. H.-R. Wessels and H. Clairmont (Hamburg: Meiner, 1988). $P M=$ Philosophy of Mind, trans. W. Wallace and A. V. Miller (Oxford: Oxford University Press, $P R=$ Hegel, Elements of the Philosophy of Right, trans. H. B. Nisbet (Cambridge: Cambridge University Press, 1991). PhS = Phenomenology of Spirit, trans. A. V. Miller (Oxford: Oxford University Press, 1971).

3 This feature of Hegel's account is emphasized in Thompson (2014). Thompson rightly remarks that this clearly distinguishes Hegel's conception of objective spirit from the notion that is later employed by Wilhelm Dilthey and Nicolai Hartmann, an issue I will return to later.

${ }^{4}$ Richard Kraut offers a careful and provocative treatment of Aristotle's 'civic priority' thesis in Kraut (2002: ch. 7). Kraut argues that the civic priority thesis is best understood not as metaphysical claim, one derived from Aristotle's somewhat obscure doctrine of homonymy, but as a practical one. That is, it rests on Aristotle's contention that the good of the city is more important than the good of any single individual. For a recent defence of Aristotle's doctrine of homonymy, see Frey (forthcoming).

${ }^{5}$ For a classic treatment of Ranke's influential criticisms of Hegel, see Steinbüchel (1949). In recent work, Frederick Beiser argues that Ranke's criticisms were misconceived because Hegel himself was explicitly opposed to the use of a priori constructions in history even if in practice Hegel did set up conceptual divisions prior to analyzing the historical record (Beiser 2012: 261-66). But although Hegel criticizes the formal conception of the a priori characteristic of his predecessors, there is no reason to think that he rejected a priori approaches to history as such; in fact, he indicates that his own approach to history is rightly characterized as a prioristic in PM: $\$ 549 \mathrm{R}$.

${ }^{6}$ Heidegger (2002). This is also argued, with more detail, by Bambach (1995: 173 n. 30).

7 On the role of sociality in Being and Time, see Rousse (2013).

8 Although this is clear enough in the case of Heidegger, it is a controversial way of characterizing Wittgenstein's methodology. For a defence of this sort of reading of Wittgenstein, see Lear (1998).

9 Taylor (1975). A major exception to these generalizations about contemporary defences of objective spirit can be found in the work of Axel Honneth. Honneth clearly distinguishes between the claim that individuals must be socialized into some communicative community to be autonomous (a view he attributes to Apel and Habermas) and the distinctively Hegelian claim that genuine self-determination is only possible once specific 'institutional relations within social reality offer opportunities to achieve these aims' (Honneth 2014: 35). As we will see, the same issue that separates Honneth from Apel and Habermas, separates Hegel from his Wittgensteinian interpreters. 10 These Wittgensteinian or Heideggerian arguments are only quasi-transcendental since although they share the basic features of a transcendental argument, the claim that there is some $\mathrm{x}$ that is the condition of the possibility of some $\mathrm{y}$, they do not have the typical purpose of a transcendental argument: that of defending of some category or set of categories against sceptical attack.

11 That this is not an exclusively Anglophone affair, however, is clear from Pirmin StekelerWeithofer's influential attempts to bridge Wittgenstein and German Idealism (see, e.g., Stekeler-Weithofer 2007 and 2008). A similar approach to objective spirit can also be found in 


\section{Objective Spirit}

Testa (2009) and, to a lesser extent, Ikäheimo (2011: esp. 153). All of these readings are heavily influenced by Robert Brandom's interpretation of Hegel.

12 Forster has come to think that Hegel's thesis about the intrinsic sociality of language (and so thought) fails because it does not provide us with any reason to reject Herder's more individualistic account of meaning. According to the latter theory, which Forster now endorses, linguistic meaning depends on society only for its genesis, not for its normative purport. See Forster (2011: 164).

13 See, for example, Pinkard (1999) and Landy (2008). Nuzzo (2013) makes an argument with a similar form, though her account does not appeal to Wittgenstein.

${ }^{14}$ For an excellent recent treatment of the role of language in Subjective Spirit that resists the temptation to read Hegel as anticipating the linguistic turn, see Davis (2014).

15 For some important qualifications to these statements, see Wood (1990: 98-99).

16 This passage was brought to my attention by Peperzak 2001, which also rightly notes that this implies slaves are not 'operating within the realm of objective spirit' (243).

${ }^{17}$ For the differences between Hegel's use of these categories and Aristotle's, see Ferrarin (2007).

${ }^{18}$ It might be thought that one possible response to the textual portion of my argument would be to concede that the Philosophy of Spirit makes a teleological argument, but to deny that this is true of the earlier Phenomenology of Spirit, which, as we saw, is the centrepiece of the quasitranscendental reading of Hegel anyway. For a reading of the treatment of the Spirit chapter of the Phenomenology that is consistent with the above reading of the Philosophy of Spirit, see Alznauer (forthcoming).

${ }^{19}$ For a clear treatment of the differences between Hegel's conception of the moral self and Kant's, see Longuenesse (2013).

${ }^{20}$ In a footnote, Neuhouser himself suggests that this is very much like the position that Robert Brandom stakes out in Brandom (2007). It is important to note, though, that Rousseau never clearly commits himself to the claim that setting up a state is the only way to effect this sort of transformation - that further claim might be exclusively Hegelian. I thank Gregory Freeman for pointing this out to me.

21 All of the quotations in the next two paragraphs are drawn from these three pages.

22 For a more complete account of Hegel's criticisms of Rousseau, see Neuhouser (2000).

23 It has become quite common to emphasize the importance of social institutions in Hegel's account of freedom (see, for example, Houlgate 2005, Pippin 2008, Pinkard 2012). But recognizing the incompatibility between the teleological and quasi-transcendental reading requires more than this; it requires noting that rational and moral autonomy depend on institutions in very different senses. Rational autonomy requires certain social institutions and practices for its genesis, but once it has come into existence, it can exist without them. Only moral autonomy is constitutively social, that is, literally impossible outside the context of certain social institutions. Most existing interpretations of Hegel's theory of agency acknowledge this difference by placing these two forms of agency at different places on a single spectrum (see for, example, Pippin 2008: 191f. 12; Houlgate 2010: 155). Although this 


\section{Mark Alznauer}

is certainly correct in a sense-there are no leaps in Hegel's system-it tends to obscure the categorical distinction implied by Hegel's decision to treat them separately (in Subjective and Objective Spirit respectively). For a more detailed defence of this way of reading of Hegel's social theory of agency, see Alznauer (2015).

${ }^{24}$ Hegel says: 'As far as the Idea of the state is concerned, it makes no difference what is or was the historical origin of the state...' (PR: \$258R).

\section{Bibliography}

Alznauer, M. (2015), Hegel's Theory of Responsibility. Cambridge: Cambridge University Press.

Alznauer, M. (forthcoming), 'Spirit in the Phenomenology of Spirit', in D. Moyar (ed.), The Oxford Handbook of Hegel. Oxford: Oxford University Press.

Beiser, F. (2012), The German Historicist Tradition. Oxford: Oxford University Press.

Bambach, C. R. (1995), Heidegger, Dilthey, and the Crisis of Historicism. Cornell: Cornell University Press.

Brandom, R. (1998), Making It Explicit: Reasoning, Representing, and Discursive Commitment. Cambridge MA: Harvard University Press.

Brandom, R. (2007), 'The Structure of Desire and Recognition: SelfConsciousness and Self-Constitution', Philosophy and Social Criticism 33:127: 127-50.

Brandom, R. (2009), 'Autonomy, Community, Freedom', in Reason in Philosophy: Animating Ideas. Cambridge MA: Harvard University Press.

Davis, A. (2014), 'Hegel's Metaphysics: Language and Truth', Lecture given at the 23rd Biennial Meeting of the Hegel Society of America, Northwestern University, Evanston IL.

Descombes, V. (2014), The Institutions of Meaning: A Defense of Anthropological Holism, trans. A. Schwartz. Cambridge MA: Harvard University Press.

Dilthey, W. (1910), 'Der Aufbau der geschichtlichen Welt in den Geisteswissenschaften', Abhandlungen der Preußischen Akademie der Wissenschaften. Philosophisch- Historische Klasse, Jg. 1910, 1-123.

Dilthey, W. (1976), Dilthey: Selected Writings, ed. H. P. Rickman. Cambridge: Cambridge University Press.

Ferrarin, A. (2007), Hegel and Aristotle. Cambridge: Cambridge University Press. Forster, M. (1998), Hegel's Idea of a Phenomenology of Spirit. Chicago: University of Chicago Press.

Forster, M. (2011), German Philosophy of Language: From Schlegel to Hegel and Beyond. Oxford and New York: Oxford University Press. 


\section{Objective Spirit}

Frey, C. (forthcoming), 'From Blood to Flesh: Homonymy, Unity, and Ways of Being in Aristotle', Ancient Philosophy.

Heidegger, M. (2002), 'Wilhelm Dilthey's Research and the Struggle for a Historical Worldview', in J. van Buren (ed.), Supplements. Albany: SUNY Press. Honneth, A. (2014), Freedom's Right. New York: Columbia University Press. Houlgate, S. (2005), An Introduction to Hegel: Freedom, Truth, and History. Oxford: Wiley-Blackwell.

Houlgate, S. (2010), 'Action, Right and Morality in Hegel's Philosophy of Right', in A. Laitinen and C. Sandis (eds.), Hegel on Action. London/New York: Palgrave Macmillan.

Ikäheimo, H. (2011), 'Holism and normative essentialism in Hegel's social ontology', in H. Ikäheimo and A. Laitinen (eds.), Recognition and Social Ontology. Leiden-Boston: Brill.

Kraut, R. (2002), Aristotle: Political Philosophy. Oxford: Oxford University Press. Landy, J. (2008), 'Hegel's Account of Rule-Following', Inquiry 51:2: 170-93.

Lear, J. (1998), 'The Disappearing "We", in Open Minded: Working Out the Logic of the Soul. Cambridge MA: Harvard University Press.

Longuenesse, B. (2013), 'Kant and Hegel on the Moral Self', in D. Emundts (ed.), Self, World, and Art: Metaphysical Topics in Kant and Hegel. Berlin/Boston: de Gruyter.

McDowell, J. (1998), Mind, Value \& Reality. Cambridge MA: Harvard University Press.

McDowell, J. (2009), Having the World in View. Cambridge MA: Harvard University Press.

McDowell, J. (2010), 'Autonomy and Its Burdens', The Harvard Review of Philosophy 17: 4-15.

McDowell, J. (2014), 'Autonomy and Community: Some Remarks on the Second Movement of Brandom's Sonata', http://cas.uchicago.edu/workshops/ germanphilosophy/files/2011/04/Autonomy-and-Community.pdf (accessed December 2014).

Neuhouser, F. (2000), Foundations of Hegel's Social Theory: Actualizing Freedom. Cambridge MA: Harvard University Press.

Neuhouser, F. (2008), Rousseau's Theodicy of Self-Love. Oxford: Oxford University Press.

Nuzzo, A. (2013), 'The Social Dimension of Dialectical Truth: Hegel's Idea of Objective Spirit', Social Epistemology Review and Reply Collective 2:8: 10-25.

Peperzak, A. (2001), Modern Freedom: Hegel's Legal, Moral, and Political Pbilosophy. Dordrecht: Kluwer.

Pinkard, T. (1999), 'Analytics, Continentals, and Modern Skepticism', The Monist 82:2: 189-217. 


\section{Mark Alznauer}

Pinkard, T. (2012), Hegel's Naturalism: Mind, Nature, and the Final Ends of Life. Oxford: Oxford University Press.

Pippin, R. (2008), Hegel's Practical Philosophy. Cambridge: Cambridge University Press.

Redding, P. (1999), The Logic of Affect. Ithaca: Cornell University Press.

Redding, P. (2008), 'Hegel, Idealism and God: Philosophy as the Self-Correcting Appropriation of the Norms of Life and Thought', in P. Ashton, T. Nicolacopoulos and G. Vassilacopoulos (eds.), The Spirit of the Age: Hegel and the Fate of Thinking. Melbourne: re.press.

Rose, G. (2009), Hegel Contra Sociology. London: Verso.

Rousse, B. (2013), 'Heidegger, Sociality, and Human Agency', in European Journal of Philosophy. doi: 10.1111/ejop.12067.

Steinbüchel, T. (1949), 'Ranke und Hegel', in R. Stadelmann (ed.), Große Geschichtsdenker. Tübingen: Rainer Wunderlich.

Stekeler-Weithofer, P. (2007), 'Persons and Practices: Kant and Hegel on Human Sapience', Journal of Consciousness Studies 14:5-6: 174-98.

Stekeler-Weithofer, P. (2008), 'Not "I say that p" but " $p$ ' says that p": Wittgenstein and Hegel on the identity of "the Notion" and "the I", in J. Padilla Gálvez (ed.), Phenomenology as Grammar. Heusenstamm: Ontos Verlag. Taylor, C. (1975), Hegel. Cambridge: Cambridge University Press.

Thompson, K. (2014), 'Hegel's Institutionalism: Social ontology, objective spirit, and institutional agency', Hegel-Jahrbuch 1:319-24.

Testa, I. (2009), 'Second Nature and Recognition', in Critical Horizons 10:3: 341-70. Winch, P. (1958), The Idea of a Social Science. London: Routledge and Kegan Paul. Wittgenstein, L. (1953), Philosophical Investigations. Trans. G. E. M. Anscombe. Oxford: Basil Blackwell.

Wood, A. (1990), Hegel's Ethical Thought. Cambridge: Cambridge University Press. 